Final Technical Report 125-4832

DEVELOPMENT AND APPLICATION OF A PALEOMAGNETIC/GEOCHEMICAL METHOD FOR CONSTRAINING THE TIMING OF BURIAL AND OTHER

\title{
DIAGENETIC EVENTS
}

\author{
P.I.: R. Douglas Elmore \\ co-P.I.: Michael H. Engel \\ School of Geology and Geophysics \\ The University of Oklahoma \\ Norman, OK 73019
}

Prepared for the U. S. Department of Energy 


\section{PROJECT SUMMARY}

Studies of diagenesis caused by fluid migration or other events are commonly hindered by a lack of temporal control. Our results to date demonstrate that a paleomagnetic/geochemical approach can be used to date fluid migration as well as burial diagenetic events. Our principal working hypothesis is that burial diagenetic processes (e.g., maturation of organic-rich sediments and clay diagenesis) and the migration of fluids can trigger the authigenesis of magnetic mineral phases. The ages of these events can be constrained by comparing chemical remanent magnetizations (CRMs) to independently established Apparent Polar Wander Paths. Whilst geochemical (e.g. stable isotope and organic analyses) and petrographic studies provide important clues for establishing these relationships, the ultimate test of this hypothesis requires the application of independent dating methods to verify the paleomagnetic ages. Towards this end, we have used KAr dating of illitization as an alternative method for constraining the ages of magnetic mineral phases in our field areas.

We have made significant progress toward understanding the origin and timing of chemical remagnetization related to burial diagenetic processes. For example, a recently completed field study documents a relationship between remagnetization and the maturation of organic matter (Blumstein et al., 2004). We have tested the hypothesized connection between clay diagenesis and remagnetization by conducting K-Ar dating of authigenic illites in units in Scotland and Montana with CRMs (e.g., Elliott et al., 2006a; Elliott et al., 2006b). We have also developed a fluid related model for alteration and remagnetization of Appalachian red beds that involves reduction and mobilization of iron phases by hydrocarbons and precipitation of authigenic hematite as a result of the introduction of meteoric fluid recharge (Cox et al., 2005). In addition, our recent studies of fluid-related CRMs along faults in Scotland provide information on the timing and origin of fluid flow events along the Moine and Great Glen faults (Parnell et al., 2004; Blumstein et al., 2005; Elmore et al., 2006). 


\section{INTRODUCTION}

Hydrocarbon generation and expulsion, as well as the smectite to illite transformation, are diagenetic processes commonly associated with organic-rich, argillaceous rocks in foreland (e.g. Appalachian), cratonic (e.g. Illinois) basins and passive margins (e.g. Gulf of Mexico). Constraining the timing of these processes is crucial with respect to models for basin evolution which are used for oil and gas exploration. As discussed below, hydrocarbon generation and migration are directly and indirectly related to mineral authigenesis (the precipitation of magnetite and illitization, respectively), the detection and timing of which can be constrained by a combination of paleomagnetic and isotopic approaches.

Our principal working hypothesis is that burial diagenetic processes (e.g., maturation of organic-rich sediments and clay diagenesis) and the migration of fluids can trigger the authigenesis of magnetic mineral phases, the ages of which can be determined by comparing their chemical remanent magnetizations (CRMs) to independently established Apparent Polar Wander Paths. Whilst geochemical (e.g. stable isotope and organic analyses) and petrographic studies provide important clues for establishing these relationships, the ultimate test of this hypothesis requires the application of independent dating methods to verify the paleomagnetic ages. Towards this end, we have employed K-Ar dating and modeling of illitization as an independent method for constraining the ages of magnetic mineral phases in our field areas.

The smectite to illite conversion (either assuming a solid-state transformation or a dissolution-precipitation model for the conversion) is a well-known diagenetic process that is used to help determine the time-temperature history of basins and margins (e.g. Gulf Coast, Denver Basin). Organic matter in black shales is intimately associated with the surfaces and interlayers of clay minerals (e.g. Kennedy et al., 2002) and a connection between the conversion of smectite to illite and the thermal maturation of organic-rich sediments is well established (see Pevear, 1999 for a recent review). Waters released during the conversion of smectite to illite may facilitate the expulsion of oil and gas from source rocks (e.g. Burst, 1969). Saline fluids have also been implicated with respect to the migration of hydrocarbons over long distances in foreland basins (Oliver, 1992). Consequently, the measurement of the age of the smectite to illite conversion either directly or estimated by use of established kinetic models (Elliott and Matisoff, 1996; Pevear, 1999) is important to help determine the timing of hydrocarbon generation and migration, critical information with respect to frontier exploration.

We have made significant progress toward understanding the origin and timing of chemical remagnetization related to burial diagenetic processes. For example, a recently completed field study suggests a relationship between remagnetization and the maturation of organic matter in Mississippian carbonates in Utah (Blumstein et al., 2004). Other field studies also suggest a connection between the smectite to illite transition and acquisition of a CRM (e.g., Katz et al., 2000; Woods et al., 2002; Gill et al., 2002). We have tested this hypothesized connection by conducting K-Ar dating of authigenic illites in units with CRMs (e.g., Elliott et al., 2006a; Elliott et al., 2006b). The results of laboratory simulation experiments also support a connection between burial diagenesis and authigenesis of magnetite (Moreau et al., 2005). We are also developing/testing a fluid related model for alteration and remagnetization of Appalachian red beds that involves reduction and mobilization of iron phases by hydrocarbons and precipitation of authigenic hematite as a result of the introduction of meteoric fluid recharge (Cox et al., 2005). In addition, our studies of fluid-related CRMs along faults in Scotland provide information on the timing and origin of fluid flow events along faults (Elmore et al., 2003; Parnell et al., 2004; Blumstein et al., 2005; Elmore et al., 2006). Paleomagnetic dating is emerging as an important method for determining the age of diagenetic processes, many of which could previously only be estimated from models. 


\section{SUMMARY OF RESEARCH}

During the past year our research supported by DOE has focused on testing burial as well as fluid related diagenetic remagnetization mechanisms. Summaries of this research are provided below.

\section{Burial Diagenetic Remagnetization Mechanisms}

We have focused on two burial diagenetic remagnetization processes: clay diagenesis and maturation of organic matter. The formation of authigenic magnetite during clay diagenesis is based on the following scenario. Illite can form at the expense of smectite at burial to depths greater than $2 \mathrm{~km}$ by either transformation or dissolution-precipitation processes (e.g., Moore and Reynolds, 1997). If the smectites are iron-rich or contain iron in the layered structure, then iron is released as a result of the conversion to illite (Boles and Franks, 1979). In closed systems, potassium, which is needed for illitization, is derived from the decomposition of potassium feldspars (e.g., Gulf Coast, Hower et al., 1976). In open systems (e.g. where there have been migrating basinal solutions), the source of potassium may be migrating saline brines or connate basin waters (Elliott and Haynes, 2002). The relationship between CRM and smectite illitization is well established from paleomagnetic, rock magnetic and geochemical study of Mesozoic carbonates in the Vocontian Trough in SE-France (Katz et al. 1998a; Katz et al., 2000). In these studies, the hypothesized acquisition of a CRM occurred during burial diagenesis of smectite.

Our previous studies have also provided evidence for a relationship between remagnetization and maturation of organic matter. For example, in a regional study of the Belden Formation, Colorado, Banerjee et al. (1997) reported that the timing of CRM acquisition is different across the basin and it agrees with the modeled time of maturation of organic matter for different localities. In addition, a collaborative study with colleagues at ORNL on the oxygen isotopes of diagenetic magnetite in the Belden indicates that the magnetite formed from water having $\delta^{18} \mathrm{O}$ near $0^{\circ} \%$ or less, implying a meteoric or connate source rather than a highly evolved orogenic or basinal fluid (Ripperdan et al., 1998). The results of these studies are consistent with a study of a single fold in the Belden which indicates that a synfolding CRM which resides in authigenic magnetite that rims pyrite grains is not related to syndeformational orogenic fluids (Fruit et al., 1995). The results are also consistent with a study of organic-rich beds in the Old Red Sandstone (Scotland) where the time of CRM acquisition agrees with independent estimates for the time of thermal maturation (Plaster-Kirk et al., 1995). Simulation experiments have also successfully produced magnetite by dissolution-reprecipitation of pyrite (Brothers et al., 1996). These experiments may simulate diagenesis at temperatures below $100^{\circ} \mathrm{C}$ and is one possible pathway for magnetite authigenesis. A study of organic-rich Jurassic sedimentary rocks adjacent to a Tertiary dike in Scotland, investigated as an analog for burial heating, suggest that moderate burial depth might be sufficient to cause magneto-chemical changes (Katz et al., 1998b). The recently completed study of the Mississippian Deseret Limestone in Utah suggests a relationship between remagnetization and the maturation of organic matter in Mississippian carbonates in Utah (Blumstein et al., 2004).

\section{Clay Diagenesis and Remagnetization in Jurassic Sediments of Skye, Scotland}

The clay fractions of Jurassic marls in the Great Estuarine Group in southern Isle of Skye are composed of mixed-layered illite-smectite (I-S) with high percentages $(>85 \%)$ of illite layers, kaolinite, and generally smaller amounts of chlorite (Basu et al., 2004; Elliott et al., 2006a). These marls have not been buried to the depths normally required to convert smectite to illite-rich I-S, so it is possible that the conversion was in response to heat and hydrothermal fluids from nearby early Tertiary igneous activity about $55 \mathrm{Ma}$ ago. The high percentages of illite layers in I$\mathrm{S}$, the Środon Intensity ratios, and the Kübler index values are consistent with the formation of 
diagenetic I-S as a result of relatively brief heating caused by igneous activity. The Jurassic rocks in southern Skye contain a secondary chemical remanent magnetization (CRM) that resides in magnetite and formed at approximately the same time as the Tertiary igneous rocks on Skye. However, K-Ar age values for I-S based on Illite Age Analysis have been determined to test the hypothesis that the CRM was acquired coincidently with the smectite-to-illite conversion. Linear regression of K-Ar age on percentage of $2 M_{1}$ polytype (detrital illite) from one marl (EL-6) yields an estimate for the age of diagenetic illite of $106 \mathrm{Ma}$ which is close to the measured age of the finest subfraction (108 Ma). These estimated and measured age values, however, could be substantially older than the true age of the diagenetic illite in I-S because of the presence of detrital $1 M_{\mathrm{d}}$ illite that was recycled from early Paleozoic shales and whose importance relative to the diagenetic I-S may have been enhanced in the presence of K-poor diagenetic fluid.

\section{Thrust Loading and Clay Diagenesis, Montana}

In this study (Elliott et al., 2006b), we test a burial model for diagenetic illite and whether illitization is related to the acquisition of a chemical remanent magnetization (CRM). A prefolding, reversed polarity, secondary magnetization is found in carbonate concretions in diagenetically altered Upper Cretaceous rocks in the disturbed belt of Montana. Stratigraphically equivalent unaltered rocks to the east do not contain the magnetization. The magnetization could be a CRM or a thermoviscous remagnetization. The pole position is generally consistent with the Early Tertiary K-Ar ages of diagenetic illite-smectite formed under thrust loading, but it is not constrained well enough for a precise age comparison. If this magnetization is a CRM, it could be related to illitization. Alternatively, if the prefolding CRM had been acquired prior to thrust loading then the magnetization is not related to illitization. Geochemical studies are currently underway to test if the magnetization could be related to fluid alteration.

\section{Fluids and CRMs}

\section{Remagnetization of Upper Devonian Sandstones in the Appalachian Provinces of West Virginia: A Reduction/Reoxidation Model}

Samples of red and green fluvial to marine sandstones of the Hampshire Formation/Catskill Group were analyzed from regional-scale folds across the structural trend of the Valley and Ridge (VR) and Appalachian Plateau (AP) provinces of West Virginia to develop a model for remagnetization of red sandstones (Cox et al., 2003, Cox et al., 2005). The red sandstones contain a Permian magnetization with southerly declinations and shallow inclinations that resides in hematite and is interpreted as a CRM. Specimens from green sandstone have weak intensities and do not contain the component. Incremental fold tests for the component yield generally prefolding results from the AP and synfolding results from the VR, thus remanence acquisition likely occurred within the time span of structural development. Thin section analysis shows the presence of authigenic specularite cement and submicron red pigment.

Geochemical/fluid inclusion studies (Evans and Battles, 1999) indicate the rocks were exposed to mixed methane-saturated formational and meteoric fluids only with no evidence that external hot orogenic fluids altered the rocks. A working model for CRM acquisition involves 1) methane reduction of previously formed iron phases and mobilization of iron, and 2) a return to oxidizing conditions and precipitation of new authigenic hematite as a result of the introduction of meteoric fluids just prior to and during uplift (e.g., Garven, 1995). The green sandstones could be a relic of the reduction phase although they may have formed as a result of gleying which occurs in paleosols (e.g., Retallack et al., 2003). 


\section{Remagnetization and Fluid Migration along Faults in the Caledonides, Scotland}

For the past several years we have investigated the role of faults as fluid conduits in Scotland (e.g., Elmore et al., 2002). Faults can act as barriers to flow or they can be conduits for flow, thereby controlling the distribution of diagenetic alteration, mineralization, and remagnetization (e.g., Knipe, 1993). For example, a study of the Highland Boundary fault (HBF) in Scotland suggests there were multiple flow events along the fault in the late Paleozoic (Elmore et al., 2002). The fluids could be related to the intrusion of Carboniferous dikes in central Scotland and/or the reactivation of the HBF in the Carboniferous-Permian. The study of the Moine Thrust Zone in the Caledonides of Scotland suggests that there were four fluid flow events along the fault between the Devonian and early Tertiary (Elmore et al., 2003; Blumstein et al., 2005). These localized CRMs coincide with post-Caledonian events such as the migration of hydrothermal fluids related to Devonian igneous activity, regional crustal extension of Scotland and NW Europe in the Permian, possible Proto-Atlantic rifting in the Triassic, and Tertiary intrusions.

The Devonian Old Red Sandstone in the vicinity of the Great Glen Fault (GGF) in Scotland contains two different components residing in hematite: a post folding Carboniferous CRM1 in the Loch Ness area and a Cretaceous or perhaps Triassic CRM2 near Hilton. The CRM1 could be related to major fluid flow events in the Late Paleozoic which caused hematite authigenesis and remagnetization along other faults in Scotland. The CRM2 near Hilton was also related to a fluid event in the Cretaceous or Triassic which also caused hematite authigenesis. The presence of different CRMs residing in hematite along different segments of the GGF is similar to what has been reported for other major faults in Scotland.

The aforementioned studies are providing evidence that dormant faults or fault systems can be conduits for localized fluid flow events at different times. Since the CRMs are younger than the Caledonian orogeny, they are not necessarily related to major orogenic events (i.e. continent-continent collision; Oliver, 1992) bur can be related to more localized igneous activity as well as tectonic events such as regional crustal extension.

We also conducted a paleomagnetic study of sandstone dikes in basement rocks in Scotland which provides evidence for syndepositional faulting during the deposition of the Torridon Group ( $900 \mathrm{Ma})$ (Myers-Dulin et. al., 2005). Although this was not a major focus our research, it is a useful application of paleomagnetism to the study of faults.

\section{Remagnetization and Fluid Migration in Madison Group Carbonates, Montana}

Paleomagnetic data and rock magnetic results suggest that a widespread orogenic remagnetization caused a pervasive chemical remanent magnetization (CRM) that resides in magnetite in the Mississippian Madison Group in the Sawtooth Range, Montana, during the Late Cretaceous to Early Tertiary (O'Brien et al., 2006). The CRM is similar to a CRM reported by workers from equivalent units in the southern Canadian Cordillera. The CRM is interpreted to be related to alteration by fluids, and there are two likely fluids: hydrocarbons which migrated into the unit and externally derived radiogenic fluids.

\section{SUMMARY}

Studies of diagenesis caused by fluid migration or other events are commonly hindered by a lack of temporal control. Our research addressed this issue and provides a foundation for the development of a paleomagnetic approach to date diagenetic events. This approach can provide timing information on rocks that are difficult to date using other techniques, as well as complementing other dating techniques (e.g., K-Ar; Ur-Pb). 
Clay-mineral modifications during diagenesis are important because they can reveal fundamental changes in the water and organic matter content and the potential for fluid migration (Chamley, 1994). The timing of the smectite to illite transition is commonly synchronous with the maturation of organic matter to form hydrocarbons and the determination of timing relative to trap formation can lead to successful hydrocarbon exploration models (e.g. Pevear, 1999; Kennedy et al., 2002). Our field studies and laboratory simulation experiments provide compelling evidence for a connection between clay diagenesis and magnetite authigenesis.

\section{STUDENT PARTICIPATION}

The P.I. (Elmore) and co-P.I. (Engel) for this proposal have combined their respective talents in sedimentology/paleomagnetism and stable isotope/organic geochemistry on the study of burial and fluid-related diagenetic procsses. Numerous students (10 M.S. and 4 Ph.D.) have been involved in the projects and most have gone on to work in the oil industry.

Kerry Moreland, a M.S. candidate, finished her M.S. thesis on the paleomagnetism of the Paleozoic limestones in the Sawtooth Mountains. Eric Cox has completed his thesis on the red beds in West Virginia. Vanessa O'Brien will complete her M.S. thesis on the geochemistry and paleomagnetism of the Madison Formation in the Disturbed belt, Montana in the spring of 2006. Louise Totten has completed her M.S. thesis on the organic geochemistry of the Mesozoic rocks that carry CRMs in the Disturbed belt, Montana. Shannon Myers-Dulin has completed the study of the sandstone dykes in Scotland and the paper has been published. She is also helping with the Great Glen project. She graduates in the spring. Students that have completed their degrees with prior support from our DOE grants are Dr. D. Fruit (Ph.D.), L. Plaster-Kirk (M.S.), T. Campbell (M.S.), K. Brisman (M.S.), G. Bixler (M.S.), S. Banerjee (Ph.D), B. Katz (Ph.D), M. Davidson (M.S.), S. Woods (M.S.), Jeff Gill (M.S.), A. Blumstein (M.S.), R. Blumstein (M.S.), and Monika Cogoini (Ph.D.).

\section{REFERENCES}

Banerjee, S., M. Engel, and R. D. Elmore, 1997, Chemical remagnetization and Burial Diagenesis of organic matter: Testing the hypothesis in the Pennsylvanian Belden Formation, Colorado: JGR, 102, 24825-24842.

Basu, A., W. Elliott, J. Wampler, R. Elmore, M.Engel, 2003, Remagnetization and Clay diagenesis in Jurassic Sediments of Skye, Scotland, Eos Trans. AGU, 84(46), Fall Meet. Suppl., Abstract V51H-0381.

Blumstein, A., Elmore, R. D., and Engel, M.H., Elliott, C. and Basu, A. 2004, Paleomagnetic Dating of Burial Diagenesis in Mississippian Carbonates, Utah, JGR, 109, B04101,doi:10.1029/2003JB002698,2004. 
Blumstein, R., Elmore, R. D., Engel, M., Parnell, J. and Baron, M., 2005, Date and Origin of Multiple Fluid Flow Events along the Moine Thrust Zone, Scotland, Journal of the Geological Society, London, 162, 1031-1045.

Boles, J.R. and Franks, S.G., 1979, Clay diagenesis in Wilcox sandstones of southwest Texas: Implications of smectite diagenesis on sandstone cementation, Sedimentary Petrology, 49, 1, 0055-0070.

Brothers, L.A., Engel, M.H., and Elmore, R.D., 1996, A laboratory investigation of the late diagenetic conclusion of pyrite to magnetite by organically complexed ferric iron, Chemical Geology, 130, 1-14.

Burst, J.F., 1969, Diagenesis of Gulf Coast Clayey sediments and its possible relation to petroleum migration: AAPG Bulletin, v. 53, p. 73-93.

Chamley, H., 1994, Clay mineral diagenesis, in Quantitative Diagenesis: Recent Developments and Applications to Reservoir Geology, Edited by A. Parker and B. Sellwood, NATO ASI Series V., 453, 161-188.

Cox, E, R. D. Elmore, M. Evans, 2003, Paleomagnetic characteristics of upper Devonian redbeds in the Valley and Ridge and Appalachian Plateau Provinces, West Virginia and Maryland, Eos Trans. AGU, 84(46), Fall Meet. Suppl., Abstract GP41D-06.

Cox, E., Elmore, R.D. and Evans, M., 2005, Paleomagnetism of Devonian red beds in the Appalachian Plateau and Valley and Ridge Provinces, JGR, V. 110, B08102.

Elliott, W.C, and Haynes, J., 2002, The chemical character of fluids forming diagenetic illite in the southern Appalachian Basin: American Mineralogist, v. 87, 1519-1528.

Elliott, W.C. and Matisoff, G., 1996, Evaluation of kinetic models of the smectite to illite transformation: Clays and Clay Minerals, v. 44, p. 77-87.

Elliott, W.C. A. Basu, J. Marion Wampler, R. D. Elmore, 2006a, Comparison of K-Ar Ages of Diagenetic IlliteSmectite to the Age of a Chemical Remanant Magnetization (CRM):An Example from the Isle of

Skye,

Scotland, Clays and Clay Minerals, submitted.

Elliott, W. C., Osborn, S., O’Brien, V., Elmore, R. D., Engel, M.H., and Wampler, M., 2006b, A Comparison of K-Ar Ages of Diagenetic Illite and the Age Implications of a Remagnetization in the Cretaceous Marias River Shale, Disturbed Belt, Montana. Geofluids V volume, J. Geochem. Exploration, in press.

Elmore, R. Douglas, Dulin, Shannon, Engel, Michael H., and Parnell, John, 2006, Remagnetization and fluid flow in the Old Red Sandstone along the Great Glen Fault, Scotland. Geofluids V volume, J. Geochem. Exploration, in press.

Elmore, R. D., Blumstein, R.. Engel., M., and J. Parnell, 2003, Paleomagnetic Dating of fluid-flow events along the Moine Thrust Zone, Scotland, J. Geochemical Exploration, v. 78-79, 45-49.

Elmore, R. D., J. Parnell, M. Engel, S. Woods, M. Abraham, and M. Davidson, 2002, Paleomagnetic Dating of fluid-flow events in dolomitized Caledonian basement rocks, central Scotland, Geofluids, 2, 299-314.

Evans, M. A., and Battles, D. A., 1999, Fluid inclusion and stable isotope analysis of veins from the central Appalachian Valley and Ridge province: implications for regional synorogenic hydrologic structure and fluid migration: Geological Society of America Bulletin, v. 111, p. 1841-1860.

Fruit, D., Elmore, R.D., Halgedahl, S., 1995, Remagnetization of the folded Belden Formation, NW Colorado: JGR, 100, 15009-15024.

Garven, G., 1995, Continental-scale groundwater flow and geological processes. Annual Review of Earth and Planetary Sciences, 24, 89-117.

Gill, J.D., Elmore, R. D., and Engel, M.H., 2002, Chemical remagnetization and clay diagenesis: Testing the hypothesis in the Cretaceous sedimentary rocks of northwestern Montana, Physics and Chemistry of the Earth, 27/25-31, 1131 1139.

Hower, J., Eslinger, E.V, Hower, M., Perry, E.A., 1976, The The mechanism of burial metamorphism of argillaceous sediments:1. mineralogical and chemical evidence: GSA Bulletin, v. 87, 725-738.

Katz, B., R. D. Elmore, M. H. Engel, M. Cogoini, \& S. Ferry, 2000, Associations between burial diagenesis of smectite, chemical remagnetization and magnetite authigenesis in the Vocontian Trough of SE-France. Journal of Geophysical Research, v. 105, 851-868.

Katz, B., Elmore, R. D., Cogoini, M. \& Ferry, S., 1998a, Widespread chemical remagnetization: Orogenic fluids or burial diagenesis of clays? Geology, 26, 603-606.

Katz, B., R. D. Elmore, and M.H. Engel, 1998b, Authigenesis of magnetite in organic-rich sediment next to a dike: Implications for thermoviscous and chemical remagnetizations, EPSL, 163, 221-234.

Kennedy, M.J., Pevear, D.R. and Hill, R.J., 2002, Mineral surface control of organic carbon in black shale, Science 295, 657-660.

Knipe. R.J., 1993, The influence of fault zone processes and diagenesis on fluid flow. In Diagenesis and Basin Development, ed. by A. D. Hobury and A. G. Robinson, AAPG Studies in Geology, \#36, 135-154.

Moore, D.M, and Reynolds, R.C., Jr., 1997, X-ray diffraction and the identification of clay minerals: Oxford University Press, 378p.

Moreau, M.G., Ader, A., and Enkin, R. J., 2005, The magnetization of clay-rich rocks in sedimentary basins: Lowtemperature experimental formation of magnetic carriers in natural samples, EPSL, 230, 193-210. 
Myers-Dulin, Shannon, Elmore, R.D., Engel, M.H., Parnell, J., and Kelly, J., 2005, Paleomagnetic dating of clastic dikes in Proterozoic basement, northwest Scotland: Evidence for syndepositional faulting during deposition of the Torridonian Sandstone, Scotish J. Geology, 41, 149-157.

O'Brien, V. J., Elmore R. D., and Engel, M., 2006, Timing and Origin of Orogenic Remagnetizations in Mississippian Carbonates, Sawtooth Range, Montana. Geofluids V volume, J. Geochem. Exploration, in press.

Oliver, J., 1992, The spots and stains of plate tectonics: Earth Sci. Rev., 32, 77-106.

Parnell, J., Watt, G., Chen, H., Wycherley, H., Boyce, A., Elmore, R. D., Blumstein, R. D., Engel, M. H., \& Green, P. 2004, Kaolin polytype evidence for a hot fluid pulse along Caledonian thrusts during rifting of the European Margin. Mineralogical Magazine 68, 419-432.

Pevear, D. R., 1999, Illite and Hydrocarbon Exploration: Proc. National Academy of Sciences, v. 96, 3440-3446.

Plaster-Kirk, L., Elmore, R.D., Engel, M.H., and Imbus, S.W., 1995, Paleomagnetic investigation of organic-rich lacustrine deposits, Middle Old Red Sandstone, Scotland, Scot. J. Geology, 31, 97-105.

Retallack, G. J., Sheldon, N., Cogoini, M., and Elmore, R. D., 2003, Magnetic Susceptibility of early Paleozoic and Precambrian paleosols. Paleo3, 198, 373-380.

Ripperdan, R. L., L. Riciputi, D. Cole, R. D. Elmore, S. Banerjee, and M.H.Engel, 1998, SIMS measurement of oxygen isotope ratios in authigenic magnetites from the Belden Formation, Colorado: JGR, 103, 21015-21024.

Woods, S., Elmore, R. D., and M. Engel, 2002, Paleomagnetic dating of the smectite-to-illite conversion: testing the hypothesis in Jurassic sedimentary rocks, Skye, Scotland, Journal of Geophysical Research, 107, 10.1029/2000JB000053, EPM 2-1-2-12. 


\section{List of Publications-Current grant (2004-2005)}

\section{Papers}

O’Brien, V. J., Elmore R. D., and Engle, M., 2006, Timing and Origin of Orogenic Remagnetizations in Mississippian Carbonates, Sawtooth Range, Montana. Geofluids V volume, J. Geochem. Exploration, in press.

Elmore, R. Douglas, Dulin, Shannon, Engel, Michael H., and Parnell, John, 2006, Remagnetization and fluid flow in the Old Red Sandstone along the Great Glen Fault, Scotland. Geofluids V volume, J. Geochem. Exploration, in press.

Elliott, W. C., Osborn, S., O’Brien, V., Elmore, R. D., Engel, M.H., and Wampler, M., 2006, A Comparison of K-Ar Ages of Diagenetic Illite and the Age Implications of a Remagnetization in the Cretaceous Marias River Shale, Disturbed Belt, Montana. Geofluids V volume, J. Geochem. Exploration, in press.

Elliott, W.C. A. Basu, J. Marion Wampler, R. D. Elmore, 2005, Comparison of K-Ar Ages of Diagenetic Illite-Smectite to the Age of a Chemical Remanant Magnetization (CRM): An Example from the Isle of Skye, Scotland, Clays and Clay Minerals, submitted.

Cox, E, R. D. Elmore, and M. Evans, 2004, Paleomagnetism of Devonian Red Beds in the Appalachian Plateau and Valley and Ridge Provinces, JGR. V. 110, B08102.

Blumstein, R., Elmore, R. D., Engel, M., Parnell, J. and Baron, M., 2005, Date and Origin of Multiple Fluid Flow Events alogn the Moine Thrust Zone, Scotland, Journal of the Geological Society, London, 162, 1031-1045.

Myers-Dulin, Shannon, Elmore, R.D., Engel, M.H., Parnell, J., and Kelly, J., 2005, Paleomagnetic dating of clastic dikes in Proterozoic basement, northwest Scotland: Evidence for syndepositional faulting during deposition of the Torridonian Sandstone, Scottish J. Geology, 41, 149-157.

Blumstein, A. M., R. D. Elmore, M. H. Engel, C. Elliot, and A. Basu (2004), Paleomagnetic dating of burial diagenesis in Mississippian carbonates, Utah, J. Geophys. Res., 109, B04101, doi:10.1029/2003JB002698.

Parnell, J., Watt, G., Chen, H., Wycherley, H., Boyce, A., Elmore, R. D., Blumstein, R., Engel, M. H., \& Green, P. 2004. Kaolin polytype evidence for a hot fluid pulse along Caledonian thrusts during rifting of the European Margin. Mineralogic Magazine, 68, 419-432.

\section{Abstracts}

Walker, D. , Elmore, R. D., and Bloomfield, K., 2004, Remagnetization and the timing of organic matter maturation in the Woodford Shale, Oklahoma, Unconventional Energy Resources in the Southern Midcontinent Conference, Oklahoma Geological Survey, March 9-10, Oklahoma City.

O’Brien, Vanessa, Moreland, Kerry, Elmore, R.D., and Dulin, Shannon A., Orogenic remagnetizations, Sawtooth Mountains, Montana, 2004, , Geological Society of America Abstracts with Programs, Vol. 36, No. 5, abs.69-14.

Engel, M.H., Elmore, R. D., O’Brien, V.J., Totten, L.A., Imbus, K., and Zumberge, J.E., 2005, Organic matter maturation and the acquisition of CRMs in the Sawtooth Mountains, Montana. 22 International Organic Geochemistry Meeting, 2005.

O’Brien, V. J., Elmore R. D., and Engel, M., 2005, Timing and Origin of Orogenic Remagnetizations in Mississippian Carbonates, Sawtooth Range, Montana. AGU Fall 2005 meeting. 
Totten, Matt, Vanessa O'Brien, and R. D. Elmore, 2006, The origin of magnetizations In Cretaceous sediments, Disturbed Belt, Montana, GSA Abstracts with Programs Vol. 38, No. 1 , in press.

\section{Unpublished Presentations}

Elmore, R. D., Blumstein, R.. Engel., M., and J. Parnell, 2003, Paleomagnetic Dating of fluid-flow events along the Moine Thrust Zone, Scotland, Geolfuids IV, poster.

\section{List of Publications-Previous grants (9/2000-9/2003)}

\section{Papers}

Elmore, R. D., J. Parnell, M. Engel, S. Woods, M. Abraham, and M. Davidson, 2002, Paleomagnetic Dating of fluid-flow events in dolomitized Caledonian basement rocks, central Scotland, Geofluids, 2, 299-314.

Elmore, R. D., Blumstein, R.. Engel., M., and J. Parnell, 2003, Paleomagnetic Dating of fluid-flow events along the Moine Thrust Zone, Scotland, J. Geochemical Exploration, v. 78-79, 45-49.

Gill, J.D., Elmore, R. D., and Engel, M.H., 2002, Chemical remagnetization and clay diagenesis: Testing the hypothesis in the Cretaceous sedimentary rocks of northwestern Montana, Physics and Chemistry of the Earth, 27/25-31, 1131 - 1139.

Woods, S., Elmore, R. D., and M. Engel, 2002, Paleomagnetic dating of the smectite-to-illite conversion: testing the hypothesis in Jurassic sedimentary rocks, Skye, Scotland, Journal of Geophysical Research, 107, 10.1029/2000JB000053, EPM 2-1-2-12.

Davidson, M., J. Egger, R. D. Elmore, M. Engel, S. Woods, and M. Abraham, 2000, Orogenic fluids and secondary magnetizations: Testing the relationship in the South Wales coalfield foreland basin, Journal of Geochemical Exploration, v. 69-70, p. 581-584.

Elmore, R. D., J. Parnell, M. Engel, S. Woods, M. Abraham, and M. Davidson, 2000, Paleomagnetic Dating of fluid-flow events in dolomitized Caledonian basement rocks, central Scotland, Journal of Geochemical Exploration, v. 69-70, p. 369-372.

Katz, B., R. D. Elmore, M. H. Engel, M. Cogoini, \& S. Ferry, 2000, Associations between burial diagenesis of smectite, chemical remagnetization and magnetite authigenesis in the Vocontian Trough of SE-France. Journal of Geophysical Research, v. 105, 851-868.

Parnell, J., Baron, M., Davidson, M., Elmore, D., \& Engel, M., 2000, Dolomitic breccia veins as evidence for extension and fluid flow in the Dalradian of Argyll. Geological Magazine, v. 137, p.447-462.

Woods, S., Elmore, R. D., and M. Engel, 2000, The occurrence of pervasive chemical remanent magnetizations in sedimentary basins: Implications for dating burial diagenetic events: Journal of Geochemical Exploration, v. 69-70, p. 381-386.

\section{Abstracts}

Cogoini, M and Elmore, R. D., 2002, Thermal Treatment of Clays Resulting in Magnetic Mineral Formation in a Smectite - An Analogy to low Burial Conditions, AGU Fall Meeting.

Miller, A., Elmore, R. D., and Engel, M.H., 2002, Paleomagnetic Dating of Burial Diagenesis in the Deseret Limestone, Utah, GSA Meeting, Denver. 
Blumstein, R., Elmore, R. D., Engel, M.H., and Parnell. J., 2002, Date and Origin of Fluid Flow Events along the Moine Thrust, Northern Scotland, GSA Meeting, Denver.

Myers-Dulin, Shannon, Elmore, R.D., Engel, M.H., Parnell, J., and Kelly, J., 2002, Paleomagnetic dating of clastic dikes in Proterozoic basement, northwest Scotland: Evidence for syndepositional faulting during deposition of the Torridonian Sandstone, GSA Meeting, Denver.

Blumstein, A., Elmore, R. D., and Engel, M.H., 2003, Origin of pre-folding and post-folding CRMs in the Deseret Limestone, Utah, Geophysical Research Abstracts, v.5, 02388, 2003.

Blumstein, R., Elmore, R. D., Engel, M.H., and Parnell. J., 2003, Date and Origin of Fluid Flow Events along the Moine Thrust, Northern Scotland, Geophysical Research Abstracts, v.5, 07059, 2003.

Cox, E, R. D. Elmore, M. Evans, Paleomagnetic characteristics of upper Devonian redbeds in the Valley and Ridge and Appalachian Plateau Provinces, West Virginia and Maryland, Eos Trans. AGU, 84(46), Fall Meet. Suppl., Abstract GP41D-06, 2003.

Basu, A., W. Elliott, J. Wampler, R. Elmore, M.Engel, Remagnetization and Clay diagenesis in Jurassic Sediments of Skye, Scotland, Eos Trans. AGU, 84(46), Fall Meet. Suppl., Abstract V51H-0381, 2003.

Cogoini, M., R.D. Elmore, M.J. McInerney, 2000, Monika Magnetic mineral formation in soils microbial versus chemical processes. GSA Abstracts with Programs, v. 32, p. A-258.

Elmore, R. D., J. Gill, S. Woods, M. Engel, 2001, Testing clay/burial diagenesis as a remagnetization mechanism. EGS meeting, March 2001.

Elmore, R. D., Engel, M., and Woods, S., 2001, A paleomagnetic/geochemical approach for constraining the timing of diagenetic events in Jurassic age sedimentary rocks from the Isle of Skye, Scotland. XX International Geochemistry Meeting, Nancy, France, Sept., 2001.

Elmore, R. D., Parnell, J., Engel, M. H., Baron, P., Woods, S, and Abraham, M., 2001, Paleomagnetic dating of a focused fluid-flow event along the Highland Boundary Fault, Scotland, GSA Abstracts with Programs, 2001 GSA Meeting, Boston.

Elmore, R. D., 2001, Remagnetization of Sedimentary Rocks, Invited talk for IAGA Meeting, Hanoi.

Elmore, R. Douglas, 2000, Paleomagnetic dating of burial/clay diagenesis, GSA Abstracts with Programs, v. 32, p. A-246.

Woods, S., R. D. Elmore, and M. Engel, 2000, Paleomagnetic dating of the smectite-to-illite conversion: Testing the hypothesis: AAPG Annual Meeting in April, 2000.

\section{Unpublished Presentations}

Elmore, R. D., J. Parnell, M. Engel, S. Woods, M. Abraham, and M. Davidson, 2000, Paleomagnetic Dating of fluid-flow events in dolomitized Caledonian basement rocks, central Scotland: Geofluids III, Conference, Barcelona, July $\backslash 2000$, oral presentation by Elmore.

Woods, S., Elmore, R. D., and M. Engel, 2000, The occurrence of pervasive chemical remanent magnetizations in sedimentary basins: Implications for dating burial diagenetic events: Geofluids III, Conference, Barcelona, July $\backslash 2000$, poster by Woods.

Davidson, M., J. Egger, R. D. Elmore, M. Engel, S. Woods, \& M. Abraham, 2000, Orogenic fluids and secondary magnetizations: Testing the relationship in the South Wales coalfield foreland basin: Geofluids III Conference, Barcelona, July 2000 , poster by Elmore.

Elmore, R. D. and Engel, M.H., 2001, Development and application of a Paleomagnetic/ geochemical method for Constraining the Timing of Fluid migration and other diagenetic Events:DOE Multiscale Reservoir Symposium, December, 2001. 
Elmore, R. D. and Engel, M.H., 2000, Testing clay diagenesis as a remagnetization mechanism and development of a paleomagnetic dating method for burial diagenetic events: DOE Geochemical Symposium, December, 2000.

\section{List of Publications (9/96-9/2000)}

Abraham, M., R. D. Elmore, M. Engel, M. Davidson, and J. Parnell, 1999, Remagnetization and Fluid Migration along the Highland Boundary Fault Zone, Scotland: 1999 Spring AGU Meeting, EOS Trans. , 80, S88.

Abraham, M., R. D. Elmore, M. Engel, M. Davidson, and J. Parnell, 1999, Remagnetization of serpentinite in the Highland Border Complex, Highland Boundary Fault zone, Scotland: Eos, Trans., v. 80, p. F288, Fall AGU Meeting.

Banerjee, S., M. Engel, and R. D. Elmore, 1997, Chemical remagnetization and Burial Diagenesis of organic matter: Testing the hypothesis in the Pennsylvanian Belden Formation, Colorado: JGR, 102, 24825-24842.

Banerjee, S. and R. D. Elmore, 1997, Chemical Remagnetization Related to Maturation of Organic Matter, Geofluids II Conference Proceedings, p. 2-5.

Banerjee, S. R. D. Elmore, M.H. Engel, R. Ripperdan, L. Riciputi, and D. Cole, 1997, Chemical remagnetization related to maturation of organic matter (abs), 18 th International Meeting on Organic Geochemistry, Maastricht, The Netherlands, September 1997.

Banerjee, S., Fruit, D., and Elmore, R.D., 1995a, Orogenic fluids and regional chemical magnetizations, Belden Formation, Colorado (abs.): AAPG National Meeting Program, v. 4, p. 14a.

Banerjee, S., Fruit, D., and Elmore, R.D., 1995b, CRM related to Diagenesic of organic matter, Belden Formation, Colorado (abs.): IUGG XXI General Assembly, B137.

Bixler, G., Elmore, R.D., and Engel, M.H., 1995a, Fluid-related chemical magnetization in Jurassic limestones from a fault zone, Kilve, England: IUGG XXI General Assembly, B137.

Bixler, G., Elmore, R.D., Engel, M.H., and Mack, L., 1995b, The origin and timing of fluid flow events in a basin-bounding fault zone, Kilve, England: Geological Society of America Annual Meeting, Abstracts with programs, 27, A-274.

Bixler, W., Katz, B., Elmore, D. and Engel, M., 1996, The origin of magnetization in Jurassic organic-rich limestones adjacent to a dike, Isle of Skye, Scotland, AGU Trans., 77.

Bixler, W. G., R. D. Elmore , and M.H. Engel, 1998, The origin of magnetization and geochemical alteration in a basin-bounding Fault Zone, Kilve, England: Geological Journal, 33, 89-105.

Brothers, L.A., Engel, M.H., and Elmore, R.D., 1995, The role of organic ligands in the diagenetic transformation of pyrite to magnetite in organic-rich carbonates: Experimental studies: 17th International Meeting on Organic Geochemistry, 5 p.

Brothers, L.A., Engel, M.H., and Elmore, R.D., 1996, A laboratory investigation of the late diagenetic conclusion of pyrite to magnetite by organically complexed ferric iron, Chemical Geology, 130, 1-14.

Davidson, Mica, Elmore, R. D., and Engel, M.H., 1998, Paleomagnetism of red dolomite veins and Dalradian Schist, Scotland. GSA, 1998 South-central Meeting, Norman, Oklahoma.

Davidson, M., R. D. Elmore, M. Engel, and J. Parnell, 1999, Fluid-related remagnetization associated with dolomite veins in the Dalradian Schist, Scotland: 1999 Spring AGU Meeting, EOS Trans., 80, S88. 
Elmore, R. D., B. Katz, and M. Engel, 1999, Paleomagnetic/geochemical approaches for constraining the timing and mechanisms for fluid migration and burial diagenesis in sedimentary basins: $19^{\text {th }}$ International Meeting on Organic Geochemistry, Instanbul, Turkey: AIGOA.

Elmore, R. D., M. H. Engel, Mica Davidson, and W. G. Bixler, 1998, Origin of magnetization in Carboniferous limestones, South Wales Coalfield, UK: AGU Trans. 79.

Elmore, R.D., Bixler, G., Plaster-Kirk, L., Andrusevich, V., Zumberge, J.E., and Engel, M.H., 1995, Application of paleomagnetics for dating hydrocarbon migration events: Case studies in northern Scotland and southern England, In: Organic Geochemistry: Development and Applications to Energy Climate, Environment and Human History, (J.O. Grimalt and C. Dorronsoro, eds.) A.J.G.O.A., San Sebastian, Spain, 278-279.

Elmore, R.D., Imbus, S., Engel, M., and Fruit, D., 1993, Hydrocarbons and magnetizations in magnetite: SEPM Special Publication \#49, pp. 181-191.

Fruit, D., Elmore, R.D., Halgedahl, S., 1995, Remagnetization of the folded Belden Formation, NW Colorado: JGR, 100, 15009-15024.

Katz, B., Elmore, R. D., Cogoini, M. \& Ferry, S., 1998, Rock Magnetic Evidence for an Association Between Burial Diagenesis of Smectite and Magnetite Authigenesis: Results From Carbonate and Clastic Rocks: 1998 Fall AGU Meeting, AGU Trans., 79, F239.

Katz, B., Elmore, R. D., Cogoini, M. \& Ferry, S., 1998, Widespread chemical remagnetization: Orogenic fluids or burial diagenesis of clays? Geology, 26, 603-606.

Katz, B., R. D. Elmore, and M.H. Engel, 1998, Authigenesis of magnetite in organic-rich sediment next to a dike: Implications for thermoviscous and chemical remagnetizations, EPSL, 163, 221-234.

Katz, B., Elmore, R. D., Cogoini, M. \& Ferry, S., 1998, Origin of magnetization in Mesozoic limestones, Vocontian Trough. 1998 Spring AGU Meeting, AGU Trans., 79.

Katz, B., Elmore, R.D. and Engel, M.H., 1997, Authigenic magnetite in the contact zone of a dike (abs), Annales Geophysicae, V. 15, EGS Meeting, Vienna.

Katz, B., R. D. Elmore, and M . Ferry, 1997, CRM and Burial Diagenesis of Smectite (abs), EGS Meeting, Annales Geophysicae, V. 15, EGS Meeting, Vienna.

Katz, B., Elmore, R. D., Cogoini, M. \& Ferry, S., 1997, The origin of widespread chemical remagnetization: Orogenic fluids or burial diagenesis of clays? GSA Abs. With Prog., 29, A379.

Katz, B., Elmore, R.D., Engel, M.H., and Leythaeuser, D., 1996, Paleomagnetism of the Jurassic Asphaltkalk-deposits, Holzen, northern Germany, Geophysical Jour., Int., 127, 305-310.

Katz, B., Elmore, R.D., and Engel, M.H., 1996, Paleomagnetism of the Jurassic Asphaltkalkdeposits, Holzen, Northern Germany, EOS, Trans., AGU, 77.

Plaster-Kirk, L., Elmore, R.D., Engel, M.H., and Imbus, S.W., 1995, Paleomagnetic investigation of organic-rich lacustrine deposits, Middle Old Red Sandstone, Scotland, Scot. J. Geology, 31, 97-105.

Ripperdan, R. L., L. Riciputi, D. Cole, R. D. Elmore, S. Banerjee, and M.H.Engel, 1998, SIMS measurement of oxygen isotope ratios in authigenic magnetites from the Belden Formation, Colorado: JGR, 103, 21015-21024.

Ripperdan, R. L., L. Riciputi, D. Cole, R. D. Elmore, S. Banerjee, and M.H.Engel, 1997, SIMS measurement of oxygen isotope ratios in authigenic magnetites from the Belden Formation, Colorado (abs): AGU Spring Meeting abstracts, 78, F150.

Woods, S., R. D. Elmore, and M. Engel, 1999, Remagnetization and the smectite-to-illite conversion: Testing the hypothesis: Eos, Trans., v. 80, p. F298.

Woods, S., R. D. Elmore, and M. Engel, 1999, Remagnetization and Clay diagenesis by Fluids: Is there a connection in Jurassic sediments of Skye, Scotland: 1999 Spring AGU Meeting, EOS, Trans., 80, S88. 